\title{
ANALISIS KETERCAPAIAN DAN KONTRIBUSI KOMPONEN PENDAPATAN ASLI DAERAH KABUPATEN GOWA
}

\author{
Nur Hidayah $^{* 1}$, Karlina Ghazalah R. ${ }^{2}$ \\ ${ }^{1,2}$ Jurusan Akuntansi, Sekolah Tinggi Ilmu Ekonomi Nobel Makassar, \\ Sulawesi Selatan, Indonesia \\ e-mail: yhayahidayah37@gmail.com
}

\begin{abstract}
ABSTRAK
Pendapatan Asli Daerah (PAD) memiliki peran penting dalam menentukan kemampuan daerah untuk menjalankan roda pemerintahan. Seiring dengan munculnya aturan daerah mandiri yang dibawa dalam Undang-undang Otonomi Daerah, maka setiap daerah harus mampu menggali potensi daerahnya masing-masing untuk pembangunan infrastruktur dan rumah tangga pemerintahan. Kabupaten Gowa merupakan daerah yang berbatasan langsung dengan Kota Makassar, ibu Kota Provinsi Sulawesi Selatan, sehingga dianggap sebagai daerah dengan jenis PAD yang beragam. Penelitian ini bertujuan untuk mengetahui (1) realisasi PAD Kabupaten Gowa, (2) index pertumbuhan komponen PAD Kabupaten Gowa dan (3) kontribusi komponen PAD Kabupaten Gowa. Data yang digunakan dalam penelitian ini berupa data time series dari laporan target dan realisasi PAD Kabupaten Gowa tahun 2014-2018. Hasil penelitian menunjukkan tingkat pencapaian dan realisasi PAD Kabupaten Gowa mengalami trend yang fluktuatif dengan nilai rata-rata 109,03\% sehingga dapat dinyatakan sangat efektif. Tingkat pertumbuhan PAD Kabupaten Gowa menunjukkan angka pertumbuhan yang fluktuatif dengan nilai rata-rata pertumbuhan 10,36\% sehingga dapat dinyatakan belum berhasil. Realisasi setiap komponen PAD berada di atas angka 100\% sehingga dapat dinyatakan sangat efektif. Kontribusi setiap komponen PAD Kabupaten Gowa cenderung stagnan dimana secara rata-rata kontributor terbesar secara berurut yaitu pajak sebesar 44,86\% (baik), retribusi sebesar $16,91 \%$ (kurang), pengelolaan kekayan daerah sebesar 35,00\% (sedang), dan pendapatan lainnya sebesar 3,24\% (sangat kurang).
\end{abstract}

Kata Kunci: Pendapatan Asli Daerah, Ketercapaian PAD, Kontribusi

\begin{abstract}
Local government own revenue called as PAD has an important role to run the government. Along with the emergence of independent regional brought under the regional autonomy of law, each region must be able to explore the potential of the regions for developing the infrastructure and government households. Gowa regency is an area directly adjacent to Makassar City, the Capital of South Sulawesi province. So, it is considered as an area with deverse type of local revenue. This study aims to disclose (1) the realization of the PAD of Gowa Regency, (2) the growth index of the PAD of Gowa Regency, and (3) the contribution of the PAD of Gowa Regency. The data used in this study are time series data from the 2014-2018 form report of target and realization of Local own revenue Gowa
\end{abstract}


Regency. The results showed the realization of PAD of the Gowa Regency experienced a fluctuating trend with an average value of $109.03 \%$ so that it could be declared very effective. The growth rate of PAD of Gowa Regency shows a fluctuating growth rate with an average growth value of $10.36 \%$ so that it can be declared unsuccessful. The realization of each component of PAD in 2014 - 2018 was above $100 \%$ so that it can be declared very effective. The contribution of each component of the PAD of Gowa Regency tends to be stagnant, on average, the largest contributor sequentially was the tax of $44.86 \%$ (good), the retribution of $16.91 \%$ (less), regional wealth management of $35.00 \%$ (moderate), and other income of $3.24 \%$ (very less).

\section{Keywords: Local own Revenue, Achievement of Revenue, Contribution}

\section{PENDAHULUAN}

Pembangunan daerah merupakan salah satu agenda pembangunan nasional yang dilaksanakan dengan tujuan memberikan kesempatan untuk pengembangan demokratisasi dan kinerja pemerintah daerah demi peningkatan kesejahteraan masyarakat dan menyelenggarakan pengembangan potensi di wilayahnya. Pemerintah daerah menyelenggarakan pengembangan demokratisasi dalam bentuk otonomi daerah yang telah dituangkan dalam UU No. 32 Tahun 2004 (Pasal 1 angka 6 dan 7) yang berisi bahwa kesatuan masyarakat hukum yang mempunyai batas daerah tertentu serta berwenang mengatur dan mengurus kepentingan masyarakat setempat berdasarkan prakarsa sendiri dan aspirasi masyarakat dalam ikatan Negara Kesatuan [1].

Fungsi dari otonomi daerah adalah menjadikan wilayah daerah mampu secara mandiri mengembangkan potensi yang ada di daerahnya sehingga tidak perlu bergantung kepada pemerintahan pusat. Pemerintah daerah selaku otoritas daerah tertinggi di wilayah harus mampu meningkatkan partisipasi masyarakat agar aktif di dalam pengembangan potensi di daerah secara mandiri. Kemandirian digunakan oleh pemerintah daerah dan membantu pengambilan keputusan dan perencanaan pembangunan infrastruktur untuk menggambarkan besarnya pendapatan dan pengeluaran serta mengukur kemampuan dan potensi daerah yang dimana tergambar di dalam APBD.

Untuk meningkatkan APBD daerah dan keluasan dalam penyusunan anggaran maka oleh daerah juga harus meningkatkan penerimaannya agar program daerah dapat terealisasi dengan baik. Pendapatan asli daerah (PAD) memiliki peran penting dalam menentukan kemampuan daerah untuk melakukan aktivitas pemerintah dan program pembangunan. Selain itu pendapatan asli daerah harus dikelola dan direalisasikan sesuai dengan APBD yang berlaku sehingga tidak ada fraud yang mengiringi. Akan tetapi, pendapatan asli daerah rata- 
rata Kota/Kabupaten ternyata masih relatif rendah. Realisasi pendapatan daerah ternyata tidak mampu menyanggupi pengembangan pembangunan daerah secara baik.

Rendahnya kemampuan daerah membiayai program-program pembangunan disebabkan rendahnya penerimaan pendapatan daerah yang dapat digali di daerahnya sendiri. Pajak-pajak yang didesentralisasikan kepada daerah kategori pajak kecil, seperti pajak reklame, pajak rumah makan, pajak perhotelan, pajak galian, dan pajak-pajak kecil lainnya. Gejala rendahnya kemampuan pemerintah daerah meningkatkan pendapatan asli daerah membuat pemerintah pusat menerapkan sistem sentralisasi pendanaan. Sistem ini digunakan karena prosedur pelaksanaanya sederhana dan adil. Sistem ini memiliki kelebihan dan kekurangan. Salah satu keuntungan dari sistem sentralisasi pendanaan adalah mengurangi kericuhan politik antar daerah yang disebabkan oleh ketidakadilan di dalam penentuan alokasi dana. Sedangkan kekurangan dari sistem ini adalah tidak terkontrolnya penyimpangan - penyimpangan program pembangunan pada saat pelaksanaan program. Oleh karena itu ketergantungan daerah kepada pemerintahan pusat dapat diukur dari dana perimbangan keuangan pusat-daerah.

Kemandirian suatu daerah dalam mengelola pendapatan asli daerahnya merupakan salah satu upaya untuk menuntaskan problema pemerintahan daerah yang terus-menerus mengalami ketergantungan dalam hal pendanaan untuk pembangunan daerah. Berdasarkan rasio kemandirian daerah, semakin tinggi rasio kemandirian mengandung arti bahwa tingkat ketergantungan daerah terhadap bantuan pihak eksternal (termasuk pemerintahan pusat dan provinsi) semakin rendah, begitupula sebaliknya. Faktor kemandirian dapat dijadikan dasar untuk melihat sejauh mana target dan realisasi pendapatan asli daerah di wilayah [2].

Efektifitas penggunaan pendapatan juga sangat berpengaruh di dalam melihat dan menilai target dan realisasi penggunaan pendapatan asli daerah. Semakin tinggi rasio efektivitas, menggambarkan kemampuan daerah yang semakin baik di dalam perencanaan dan penggunaan pendapatan asli daerah tanpa adanya bantuan dana dari pemerintahan pusat atau provinsi [2].

Pendapatan asli daerah (PAD) adalah semua penerimaan daerah yang berasal dari sumber ekonomi asli daerah yang dikelompokkan menjadi empat jenis yaitu pajak daerah, retribusi daerah, hasil perusahaan milik daerah yang dipisahkan, dan lain-lain PAD yang sah. Dengan demikian, pendapatan asli daerah merupakan sumber keuangan yang berperan penting di dalam kemakmuran rakyat di daerah [3]. 
Target pelaksanaan PAD tertuang di dalam anggaran pendapatan dan belanja daerah (APBD). Berdasarkan Pasal 64 ayat (2) Undang-Undang Nomor 5 Tahun 1974 tentang Pokok-Pokok Pemerintahan di Daerah, APBD adalah rencana operasional keuangan pemerintahan daerah, dimana di satu pihak menggambarkan perkiraan pengeluaran setinggitingginya guna membiayai kegiatan-kegiatan dan proyek-proyek daerah dalam 1 tahun anggaran tertentu, dan di pihak lain menggambarkan perkiraan penerimaan dan sumbersumber penerimaan daerah guna menutupi pengeluaran-pengeluaran daerah [4].

Seiring dengan bertambahnya tugas dan tanggung jawab daerah dalam mengatur pembangunan sendiri sebagaimana fungsi otonomi daerah, maka sumber-sumber keuangan atau pembiayaan harus lebih ditingkatkan.Untuk urusan pembiayaan pemerintah daerah maka pendapatan asli daerah harus mencukupi untuk dipakai dalam pembangunan daerah. Daerah dapat menempuh cara-cara untuk meningkatkan pendapatan asli daerah misalnya dengan intensifikasi pajak, ekstensifikasi pajak, dan peningkatan pendapatan badan-badan usaha milik daerah.

Pajak diharapkan mampu menutupi biaya pembangunan. Selain pajak daerah, retribusi daerah dapat menjadi sumber pembiayaan keuangan yang mampu meningkatkan pendapatan daerah. Retribusi daerah adalah pungutan daerah sebagai pembayaran atas jasa atau pemberian izin tertentu yang khusus disediakan dan/atau diberikan oleh pemerintah daerah untuk kepentingan pribadi atau badan. Retribusi daerah dibagi 3 seperti yang tertuang dalam UU No. 28 tahun 1999 yaitu, retribusi jasa usaha, retribusi jasa umum, dan retribusi perizinan tertentu [5].

Seiring dengan berjalannya waktu, pemerintah daerah selalu gencar memberikan rasa optimism kepada masyarakat agar selalu mendukung kinerja keuangan daerah. Hal ini dilakukan agar pendapatan daerah terus meningkat dan mencapai target serta pembangunan daerah yang telah ditargetkan melalui APBD dapat direalisasikan dengan baik. Realisasi yang baik adalah yang sesuai dengan target dan tidak menyimpang dari APBD yang telah disepakati.

Pendapatan asli daerah yang rendah dapat memicu banyak masalah salah satunya adalah tingginya pajak daerah sebagai solusi lain dari rendahnya pendapatan asli daerah. Pemerintah daerah akan meningkatkan pajak daerah di beberapa lini seperti pajak bumi dan bangunan agar bisa memacu pendapatan asli daerah. Seperti halnya yang terjadi di Kota Makassar saat ini, PAD yang rendah membuat pemerintah harus meningkatkan pajak tanah 
agar target PAD yang kurang dapat terpenuhi [6]. Sebaliknya, di Kota Jakarta bagi masyarakat yang mengurus sertifikat tanah tidak perlu membayar pajak karena PAD kota tersebut tercapai lebih dari target yang ditetapkan [7]. Target dan realisasi yang baik dari pendapatan asli daerah sangat penting mengingat PAD hadir untuk memberikan fasilitas pembangunan kepada masyarakat demi kesejahteraan masyarakat [8].

Penelitian mengenai peran pendapatan asli daerah dalam pembangunan daerah telah banyak dilakukan sebelumnya, namun, perbedaan mendasar pada penelitian ini adalah pada index nilai pertumbuhan komponen PAD. Seperti penelitian Antari dan Ida (2018) yang melihat PAD dan belanja modal terhadap kinerja keuangan pemerintah daerah di Kabupaten/Kota se-provinsi Bali. Hasil penelitian menunjukkan bahwa PAD berpengaruh positif dan signifikan terhadap kinerja keuangan dan belanja modal berpengaruh negatif signifikan terhadap kinerja keuangan pemerintah daerah [9].

Kontribusi sumber PAD kabupaten/kota seluruh Indonesia tahun anggaran 2007-2013 didominasi oleh penerimaan yang bersumber dari pajak yang dikategorikan berkontribusi baik selanjutnya lain-lain PAD yang sah, retribusi dan BUMD [10]. Nilawati (2019) melihat strategi yang dilakukan dalam peningkatan PAD di Kabupaten Gunungsari perlu untuk ditingkatkan dalam hal program dan komitmen pengelola pajak-retribusi daerah pada masingmasing OPD pengelola pendapatan, program peningkatan PAD dan implementasi rencana aksi peningkatan PAD, pemanfaatan teknologi informasi dan komunikasi untuk pengelolaan masing-masing lini PAD [11].

Tujuan penelitian ini adalah untuk mengetahui realisasi, level pertumbuhan dan kontribusi PAD pada kabupaten Gowa. Oleh karena itu, kontirbusi penelitian ini menjadi bahan umpan balik ke pemerintah daerah.

\section{METODE PENELITIAN}

Metode penelitian ini menggunakan pendekatan kuantitiatif. Pendekatan kuantitatif yaitu proses penarikan kesimpulan berdasarkan data berupa angka yang kemudian dianalisis secara matematis. Data yang digunakan pada penelitian ini berupa data time series (urutan waktu). Sumber data yang digunakan merupakan data sekunder yaitu Laporan Target dan Realisasi Pendapatan Asli Daerah Kabupaten Gowa tahun 2014 - 2018.

Teknik analisis data secara kuantitatif menggunakan analisis rasio. Adapun analisis rasio yang digunakan dapat diuraikan sebagai berikut: 


\section{a. Rasio Efektivitas PAD}

Tingkat pencapaian PAD diukur berdasarkan realisasi dari target PAD yang telah ditetapkan. Rasio pencapaian PAD menunjukkan kemampuan pemerintah merealisasikan targetnya selama satu tahun. Rumusnya ialah sebagai berikut.

$$
\frac{\text { Realisasi } P A D}{\text { Target } P A D} \times 100 \% \ldots \text { (1) }
$$

Penilaian efektivitas mengacu pada tabel berikut.

\section{Tabel 1. Kriteria Penilaian Efektivitas}

\begin{tabular}{|l|c|}
\hline \multicolumn{1}{|c|}{ Efektivitas } & Kriteria \\
\hline Lebih dari $100 \%$ & Sangat efektif \\
\hline $90 \%-100 \%$ & Efektif \\
\hline $80 \%-90 \%$ & Cukup efektif \\
\hline $60 \%-80 \%$ & Kurang efektif \\
\hline Kurang dari $60 \%$ & Tidak efektif \\
\hline
\end{tabular}

Sumber : Mujiyati, $2014{ }^{[12}$

\section{b. Pertumbuhan Realisasi PAD}

Pertumbuhan realisasi PAD dapat menunjukkan ketepatan pemerintah dalam menetapkan target pendapatan dan kemampuan pemerintah merealisasikan target apabila dibandingkan secara year to year. Rumus untuk menghitung pertumbuhan PAD ialah sebagai berikut.

\section{$\frac{\text { Realisasi PAD tahun }(n+1)-\text { Realisasi PAD tahun }(n)}{\text { Realisasi PAD tahun }(n)} \times 100 \% \ldots$ (2)}

Penilaian kriteria laju pertumbuhan mengacu pada tabel berikut.

Tabel 2. Kriteria Penilaian Laju Pertumbuhan

\begin{tabular}{|l|c|}
\hline \multicolumn{1}{|c|}{ Persentase } & Kriteria \\
\hline $85 \%-100 \%$ & Sangat berhasil \\
\hline $70 \%-85 \%$ & Berhasil \\
\hline $55 \%-70 \%$ & Cukup berhasil \\
\hline $30 \%-55 \%$ & Kurang berhasil \\
\hline Kurang dari $30 \%$ & Tidak berhasil \\
\hline Sumber $:$ Halim 2004 & {$[13]$} \\
\hline
\end{tabular}




\section{c. Rasio Efektivitas Setiap Komponen PAD}

Komponen PAD secara umum yaitu berasal dari pajak, retribusi, pengelolaan kekayaan daerah, dan pendapatan lainnya. Pada penelitian ini, komponen PAD yang dianalisis yaitu pajak, retribusi, dan pengelolaan kekayaan daerah. Rasio ketercapaian dapat menunjukkan kinerja pemerintah dalam merealisasikan target dari setiap komponen PAD, atau secara matematis dirumuskan sebagai berikut.

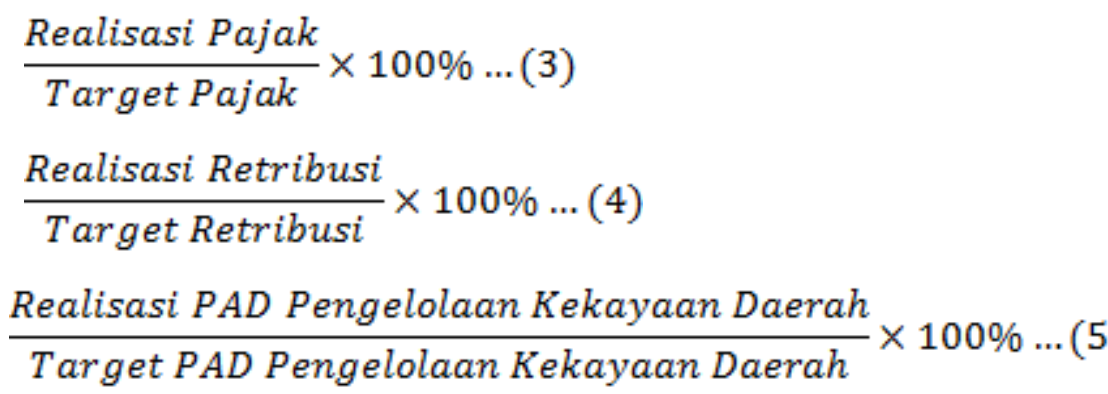

Penilaian efektivitas setiap komponen PAD mengacu pada Tabel 1.

\section{d. Kontribusi Setiap Komponen PAD}

Untuk memperoleh informasi secara detail maka perlu menganalisis kontribusi setiap komponen PAD terhadap PAD secara keseluruhan. Rumus yang digunakan yaitu sebagai berikut:

$$
\begin{aligned}
& \frac{\text { Realisasi Pajak }}{\text { Realisasi PAD }} \times 100 \% \ldots(6) \\
& \frac{\text { Realisasi Retribusi }}{\text { Realisasi PAD }} \times 100 \% \ldots(7) \\
& \frac{\text { Realisasi PAD Pengelolaan Kekayaan Daerah }}{\text { Realisasi PAD }}
\end{aligned}
$$

Untuk menilai kontribsi setiap komponen PAD maka dapat mengacu pada tabel berikut.

Tabel 3. Kriteria Penilaian Kontribusi Komponen PAD

\begin{tabular}{|c|c|}
\hline Persentase & Kriteria \\
\hline$\geq 50 \%$ & Sangat baik \\
\hline $40 \%-50 \%$ & Baik \\
\hline $30 \%-40 \%$ & Sedang \\
\hline $20 \%-30 \%$ & Cukup \\
\hline $10 \%-20 \%$ & Kurang \\
\hline$\leq 10 \%$ & Sangat Kurang \\
\hline
\end{tabular}

Sumber : Halim, $2004^{[13]}$ 


\section{HASIL DAN PEMBAHASAN}

\subsection{Hasil Penelitian}

Tabel 4. Pencapaian Realisasi PAD Kabupaten Gowa

\begin{tabular}{|c|c|c|c|}
\hline Tahun & Target (Rp) & Realisasi (Rp) & Pencapaian \\
\hline 2014 & $131,625,273,431.00$ & $149,354,075,782.00$ & $113.47 \%$ \\
\hline 2015 & $147,011,276,458.00$ & $154,812,903,101.00$ & $105.31 \%$ \\
\hline 2016 & $168,865,893,977.00$ & $191,201,751,118.00$ & $113.23 \%$ \\
\hline 2017 & $168,310,461,014.00$ & $183,255,395,345.00$ & $108.88 \%$ \\
\hline 2018 & $208,160,896,819.00$ & $217,052,216,221.00$ & $104.27 \%$ \\
\hline
\end{tabular}

Sumber : Laporan Target dan Realisasi PAD Kab. Gowa 2014 - 2018

Pada Tabel 4 dapat diperhatikan bahwa PAD tertinggi ditunjukkan pada tahun 2018 yaitu sebesar Rp. 217,052,216,221.00. Nilai tersebut mengalami peningkatan hingga 58.15\% atau senilai Rp. 67,698,140,439.00 dari tahun 2014. Mengacu pada nominal realisasi PAD maka dapat diketahui bahwa realisasi PAD Kabupaten Gowa menunjukkan angka yang fluktuatif dari tahun ke tahun.

Pencapaian tertinggi terkait rasio target dan realisasi PAD Kabupaten Gowa ditunjukkan pada data tahun 2014 yaitu 113.47\% sedangkan yang terendah pada tahun 2018 yaitu $104.27 \%$. Berdasarkan persentase rasio tingkat pencapaian PAD maka capaian realisasi PAD Kabupaten Gowa cenderung menunjukkan trend yang menurun dari tahun ke tahun. Peningkatan hanya terjadi pada interval tahun 2015 (105.31\%) ke tahun 2016 (113.23\%).

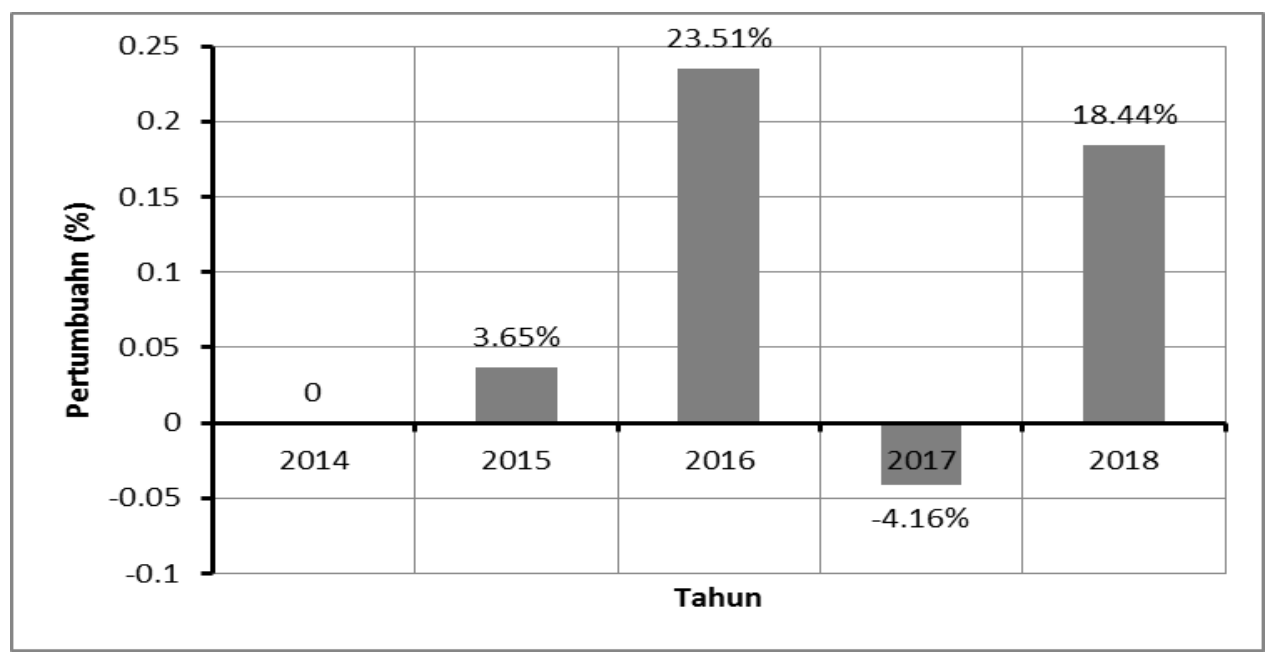

Gambar 1. Grafik Pertumbuhan Realisasi PAD Kab. Gowa 2014 - 2018 
Trend pertumbuhan PAD Kabupaten Gowa pada interval 2014 - 2018 cenderung menunjukkan grafik yang fluktuatif. Hal tersebut disebabkan adanya penurunan persentase pertumbuhan pada interval 2016 - 2017 yaitu dari 23,51\% menjadi - 4,16\%.

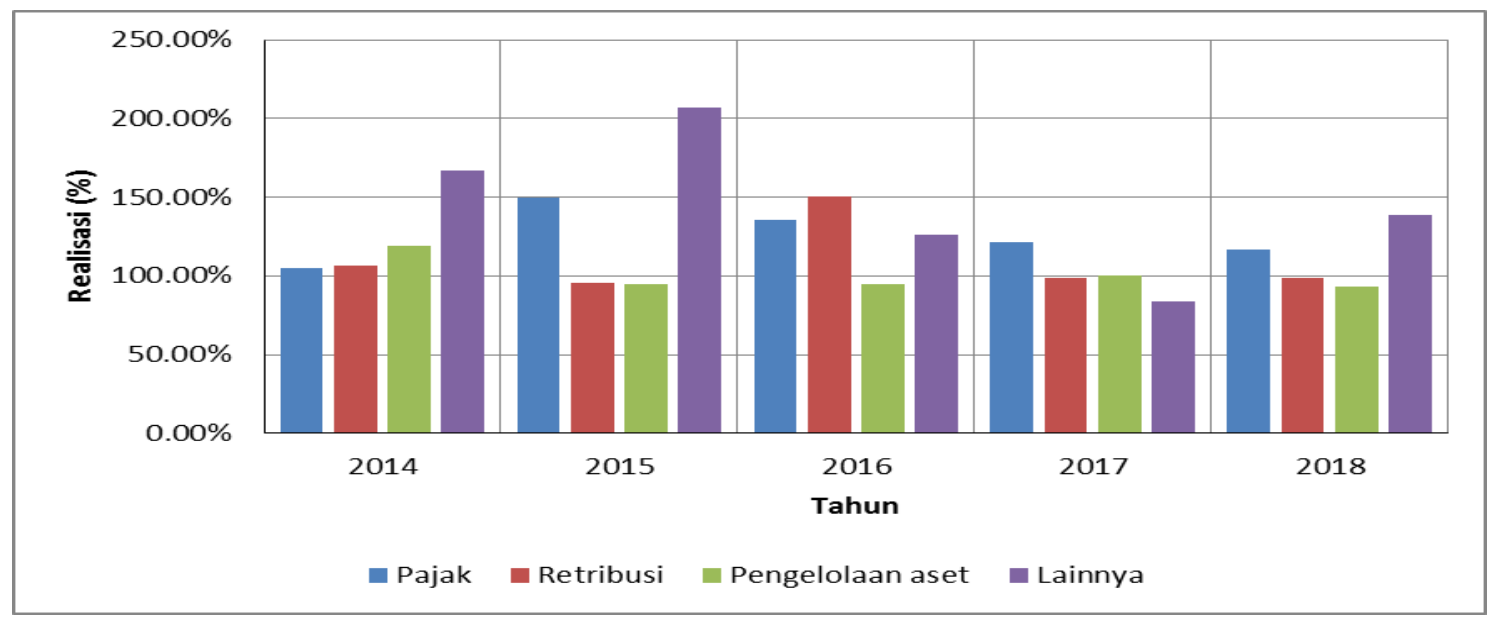

Gambar 2. Grafik Realisasi PAD Kab. Gowa 2014 - 2018 Berdasarkan Komponennya

Realisasi komponen pajak pada PAD Kabupaten Gowa menunjukkan trend menurun pada interval 2015 - 2018 yaitu dari 149.54\% menjadi 116.44\%. Realisasi komponen lainnya (retribusi, pengelolaan aset, pendapatan lainnya) bergerak secara fluktuatif dengan nilai ratarata realisasi retribusi yaitu $110.07 \%$, pengelolaan aset $100.48 \%$, dan pendapatan lainnya yang sah sebesar $144.49 \%$. Berdasarkan nilai rata-rata tersebut maka dapat dinyatakan bahwa realisasi setiap komponen PAD Kabupaten Gowa termasuk pada kategori sangat efektif.

Tabel 5. Kontribusi Setiap Komponen Terhadap Realisasi PAD Kabupaten Gowa

\begin{tabular}{|c|c|c|c|c|c|c|c|c|}
\hline Tahun & $\begin{array}{c}\text { Kontribusi } \\
\text { Pajak (\%) }\end{array}$ & Kriteria & $\begin{array}{c}\text { Kontribusi } \\
\text { Retribusi } \\
(\%)\end{array}$ & Kriteria & $\begin{array}{c}\text { Kontribusi } \\
\text { Pengelolaan } \\
\text { Kekayaan } \\
\text { Daerah (\%) }\end{array}$ & Kriteria & $\begin{array}{c}\text { Kontribusi } \\
\text { Pendapatan } \\
\text { lainnya (\%) }\end{array}$ & Kriteria \\
\hline 2014 & 41,54 & Baik & 14,9 & Kurang & 38,56 & Sedang & 5 & $\begin{array}{c}\text { Sangat } \\
\text { kurang }\end{array}$ \\
\hline 2015 & 46,25 & Baik & 16,19 & Kurang & 32,86 & Sedang & 4,7 & $\begin{array}{c}\text { Sangat } \\
\text { kurang }\end{array}$ \\
\hline 2016 & 40,88 & Baik & 23,03 & Cukup & 33,45 & Sedang & 2,65 & $\begin{array}{c}\text { Sangat } \\
\text { kurang }\end{array}$ \\
\hline 2017 & 48,97 & Baik & 14,32 & Kurang & 34,33 & Sedang & 2,38 & $\begin{array}{c}\text { Sangat } \\
\text { kurang }\end{array}$ \\
\hline 2018 & 46,65 & Baik & 16,1 & Kurang & 35,79 & Sedang & 1,46 & $\begin{array}{c}\text { Sangat } \\
\text { kurang }\end{array}$ \\
\hline $\begin{array}{c}\text { Rata- } \\
\text { rata }\end{array}$ & $\mathbf{4 4 , 8 6}$ & Baik & $\mathbf{1 6 , 9 1}$ & Kurang & $\mathbf{3 5 , 0 0}$ & Sedang & $\mathbf{3 , 2 4}$ & $\begin{array}{c}\text { Sangat } \\
\text { Kurang }\end{array}$ \\
\hline
\end{tabular}

Sumber : Laporan Target dan Realisasi PAD Kab. Gowa 2014 - 2018 
Realisasi kontribusi setiap komponen PAD Kabupaten Gowa cenderung stagnan setiap tahunnya. Selama kurun waktu 2014 - 2018 diperoleh nilai rata-rata kontribusi pajak sebesar 44,86\% dan termasuk kategori Baik, kontribusi retribusi 16,91\% termasuk kategori kurang baik, kontribusi pengelolaan kekayaan daerah sebesar 35,00\% termasuk kategori sedang, dan kontribusi pendapatan lainnya 3,24\% termasuk kategori sangat kurang.

\subsection{Pembahasan}

Tingkat pencapaian PAD diukur berdasarkan realisasi dari target PAD yang telah ditetapkan. Rasio pencapaian PAD menunjukkan kemampuan pemerintah merealisasikan targetnya selama satu tahun. Berdasarkan hasil penelitian yang dijabarkan melalui Tabel 4 menunjukkan bahwa tingkat pencapaian PAD Kabupaten Gowa pada tahun 2014-2018 mengalami peningkatan yang cukup signifikan. Hal ini terlihat dari proporsi nilai pencapaian pada tahun 2014 hingga 2018 mengalami peningkatan pencapaian hingga 58,15\% selama tahun.

Mengacu pada angka pencapaian yang melebihi $100 \%$ dengan rata-rata pencapaian 109,03\% maka dapat dikatakan bahwa realisasi PAD Kabupaten Gowa dinilai sangat efektif. Hal ini mengindikasikan bahwa pemerintah Gowa telah merealisasikan target selama 1 tahun dengan baik dan tidak menyia-nyiakan waktu untuk mengelola PAD dengan baik.

Nilai pertumbuhan realisasi PAD Kabupaten Gowa pada tahun 2014-2018 mengalami trend fluktuatif dimana pada tahun 2017 terjadi penurunan nilai pertumbuhan yang cukup berpengaruh pada Kabupaten Gowa. Menurut Bupati Kabupaten Gowa, ada beberapa pos pendapatan di dalam PAD yang tidak mencapai target yaitu retribusi daerah dan pendapatan hasil pengelolaan kekayaan daerah. Oleh karena itu pada tahun 2018 Kabupaten Gowa mampu meningkatkan pertumbuhan ekonominya belajar dari ketidaktercapaian beberapa pos di tahun 2017. Berdasarkan pertumbuhan PAD 5 tahun terakhir maka diketahui bahwa nilai pertumbuhan PAD Kabupaten Gowa tidak pernah melebihi 30\% dengan nilai rata-rata 10,36\% sehingga dapat dinyatakan bahwa Pemerintah Kabupaten Gowa belum berhasil meningkatkan pertumbuhan PAD dalam interval waktu 2014 - 2018.

Senada dengan penelitian Ramadani, dkk (2017) di Kota Samarinda, yang menunjukkan kinerja keuangan Pendapatan daerah Kota Samarinda secara umum dapat dikatakan cukup baik dengan pertumbuhan pendapatan daerah rata-rata atau pada garis positif $16,75 \%$ dan rasio efektifitas rata-rata besar dari 100\% dengan nilai 100,37\% [14]. Demikian juga Kristianti dan Berlian (2015) yang melihat pencapaian target dan efisiensi PAD Kota 
Salatiga. Hasilnya, tingkat pencapaian target realisasi pajak daerah dan retribusi daerah selama tahun 2011-2015 masuk dalam kategori sangat efektif namun kontribusi pajak daerah terhadap PAD masih dianggap kurang memberikan kontribusi [15].

Realisasi komponen pajak pada PAD Kabupaten Gowa menunjukkan trend menurun pada interval 2015 - 2018. Komponen lain seperti retribusi daerah, pengelolaan aset, dan pendapatan lainnya mengalami laju fluktuasi dari 2014 selama 5 tahun. Nilai realisasi ratarata yang ditunjukkan oleh setiap komponen menunjukkan angka di atas 100\% yaitu pajak $(125,69 \%)$, retribusi $(110,07 \%)$, pengelolaan kekayaan daerah $(100,48 \%)$, dan pendapatan lainnya $(144,84 \%)$. Oleh karena itu, realisasi setiap komponen PAD dapat dinyatakan sangat efektif.

Pengelolaan aset menjadi salah satu komponen yang mengalami trend peningkatan realisasi yang cukup tinggi. Kabupaten Gowa menjadi salah satu daerah di Sulawesi Selatan yang cukup berhasil melaksanakan pengelolaan asset hingga mampu mempertahankan opini Wajar Tanpa Pengecualian. Banyak daerah seperti Sidrap, Bone, dsb menjadikan Kabupaten Gowa sebagai daerah percontohan untuk keberhasilan pengelolaan aset terutama di daerah kabupaten. Aturan mengenai pengelolaan aset telah dibuatkan aturannya melalui Peraturan Daerah Kabupaten Gowa Nomor 7 Tahun 2018 tentang Pengelolaan Barang Milik Daerah.

Realisasi kontribusi setiap komponen PAD Kabupaten Gowa menunjukkan trend fluktuatif pada interval tahun 2014-2018. Salah satu komponen PAD yang memiliki tingkat realisasi kontribusi tinggi adalah pajak $(44,85 \%)$. Capaian tersebut tidak lepas dari upaya dan dukungan Bupati Kabupaten Gowa beserta jajarannya untuk selalu mendorong masyarakat agar patuh terhadap pajak dan wajib melaporkan Surat Pemberitahuan Tahunan (SPT) di kantor pajak.

Selain komponen pajak, pengelolaan aset juga berkontribusi optimal $(35,00 \%)$ terhadap PAD yang realisasi kontribusinya cukup meningkat selama kurun waktu empat tahun dari 2014. Hal ini tidak lepas dari kerja keras pemerintah Kabupaten Gowa dalam mendorong masyarakat untuk selalu bangga dengan aset daerah salah satunya pengelolaan aset cagar budaya seperi Balla' Lompoa. Pengeloaan aset yang baik mampu memberikan kontribusi positif terhadap capaian target PAD di Kabupaten Gowa. 


\section{KESIMPULAN}

Pencapaian PAD Kabupaten Gowa pada tahun 2014-2018 menunjukkan grafik yang fluktuatif baik dari segi realisasi maupun laju pertumbuhan PAD. Persentase pencapaian PAD pada interval tahun 2014 hingga 2018 selalu berada di angka >100\% sehingga dapat dinyatakan sangat efektif. Persentase laju pertumbuhan realisasi PAD Kabupaten Gowa pada tahun 2014-2018 mengalami hasil yang fluktuatif dan tidak pernah menunjukkan angka di atas $30 \%$ sehingga dapat dinyatakan tidak berhasil.

Realisasi komponen PAD seperti pajak, retribusi, pengelolaan aset, dan pendapatan lainnya pada tahun 2014 - 2018 menghasilkan angka yang fluktuatif. Adapun penyebab hal ini adalah beberapa realisasi komponen PAD (pajak, retribusi, dan pengelolaan aset) yang belum optimal. Realisasi kontribusi setiap komponen PAD Kabupaten Gowa menunjukkan trend yang fluktuatif pada tahun 2014-2018. Salah satu komponen PAD yang memiliki tingkat realisasi kontribusi tinggi adalah pajak dan pengelolaan aset.

Analisis ketercapaian dan kontribusi komponen PAD di Kabupaten Gowa telah menunjukkan trend yang baik walau dalam beberapa sektor masih perlu dioptimalkan. Oleh karena itu, hal ini menjadi saran yang penting bagi Pemerintah Daerah agar mampu menciptakan lingkungan yang baik dalam merealisasikan target PAD demi kesejahteraan daerah.

\section{DAFTAR PUSTAKA}

[1] Undang-Undang Nomor 32 Tahun 2004 tentang Pemerintahan Daerah

[2] Halim, Abdul. 2012. Akuntansi Sektor Publik: Akuntansi Keuangan Daerah., Edisi Keempat. Jakarta : Salemba Empat.

[3] Halim, Abdul. 2001. Akuntansi dan Pengendalian Keuangan Daerah. Yogyakarta: UPPAMP YKPN.

[4] Undang-Undang Nomor 5 Tahun 1974 tentang Pokok-Pokok Pemerintahan Daerah

[5] Undang-Undang Nomor 28 Tahun 1999 tentang Penyelenggaraan Negara yang Bersih dan Bebas dari Korupsi, Kolusi, dan Nepotisme.

[6] Rahayuanti, S, Malisan, L, Kusumawardani, A. 2018. Analisis Target dan Realisasi Pajak Daerah. Journal FEB Universitas Mulawarman Akuntabel 15 (1), hal 55-66. 
[7] Anonim. 2018. Berapa Pendapatan Asli Daerah DKI Jakarta?. Diakses pada 15 Maret 2020 dari: https://databoks.katadata.co.id/datapublish/2018/01/25/berapapendapatan-asli-daerah-dki-jakarta

[8] Indrawani, Sri. 2019. Analisis Kinerja Pengelolaan Pendapatan Asli Daerah Kota Pariaman dari Tahun 2011-2017. Jurnal Ilmu Ekonomi Terapan Vol. 4.

[9] Antari, Ni Putu dan Ida Bagus. 2018. Pengaruh Pendapatan Asli Daerah dan Belanja Modal terhadap Kinerja Keuangan Pemerintah Daerah. E-jurnal Manajemen Unud.7:1080-1110.

[10] Nasir, Muhammad S. 2019. Analisis Sumber-Sumber Pendapatan Asli Daerah setelah Satu Dekade Otonomi Daerah. Jurnal Dinamika Ekonomi Pembangunan. Vol 2: 30-45.

[11] Nilawati, Evi. 2019. Analisis dan Strategi Peningkatan Pendapatan Asli Daerah (PAD) di Kabupaten Gunungkidul. Jurnal Maksipreneur Vol 9: 41-60.

[12] Mujiyati, Della Ayu dan Lina Kusuma. 2014. Evaluasi Penerimaan Pajak Bumi dan Bangunan (PBB) Pasca UU No 28 tahun 2009 Tentang PDRD (Studi Kasus Kabupaten Sukoharjo). Seminar Nasional dan Call For Syariah Paper

[13] Halim. 2004. Akuntansi Keuangan Daerah. Jakarta: Salemba Empat.

[14] Ramadani, Rani, Elfreda dan Suyatin. 2017. Analisis Kinerja Anggaran dan Realisasi Pendapatan dan belanja Daerah Pemerintah Kota Samarinda. Jurnal Ekonomia: Vol.5 (3).

[15] Kristianti, Ika dan Berliana. 2015. Tingkat Pencapaian Target dan Efisiensi Pendapatan Asli Daerah (PAD) Kota Salatiga. Dinamika Akuntansi, keuangan dan Perbankan Vol 4: 152-160. 